\title{
Afetlerde Sosyal Hizmetler
}

\author{
Ercan ÖZÇELIKK ${ }^{1}$
}

\begin{abstract}
Özet
İnsanların geniş kitleler halinde en savunmasız ve en muhtaç olduğu zaman dilimlerinden birisi de afet halleridir. Afetler yaşanmadan önce yapılacak temel altyapı ve fiziksel hazırlıkların yanı sıra, sosyal hizmetler açısından da hazırlıkların yapılması gerekir. Çünkü sosyal hizmetlerin doğru zamanlı ve yerinde uygulamaları ile toplumsal zarar görmüşlügün en aza indirilmesi, afetlerin yıkım etkisinden toplumun sosyal ve ekonomik anlamda korunması sağlanır. Sosyal hizmetler ile afetlerden doğrudan veya dolaylı etkilenen kesimlere ulaşmak mümkün olur. Sosyal hizmetlerin içinde afetzedelere yönelik sosyal ve ekonomik destek süreçleri ile birlikte psikolojik iyileştirme ve koruma çalışmalarını da dahil etmek gerekir.
\end{abstract}

$\mathrm{Bu}$ çalışmada afetlerde sosyal hizmetler için genel kuramsal çerçeve ile birlikte paydaşların tanımlanması, istenen ve beklenen etkiler için sosyal hizmetlerin organizasyon modellemesi üzerinde durulacaktır. Sosyal hizmetlerin yerel kaynaklarla bütünleşmesi erişibilirliğini ve yaygınlığını sağlar. Bu nedenle merkezi yönetimlerin destek ve himayesinde yerel yönetimlerin ve sivil toplum örgütlerinin daha etkili olmalarını teşvik etmek gerekir.

Anahtar Kelimeler: Afet Yönetimi, Doğal Afetler, Sosyal Hizmetler

\section{Social Services in Disasters}

\begin{abstract}
One of the times when people are most vulnerable and in need of large masses is disaster situations. In addition to the basic infrastructure and physical preparations to be made before disasters occur, preparations should also be made in terms of social services. Because, with the right and timely applications of social services, it is ensured that social damage is minimized and the social and economic protection of the society from the destruction effect of disasters is ensured. With social services, it is possible to reach those directly or indirectly affected by disasters. It is necessary to include social and economic support processes for disaster victims in social services, as well as psychological improvement and protection efforts.
\end{abstract}

In this study, the definition of stakeholders along with the general theoretical framework for social services in disasters, organization modeling of social services for desired and expected effects will be emphasized. Integration of social services with local resources provides accessibility and

${ }^{1}$ Tıbbi Teknolog - Sivil Savunma Amiri, Koşuyolu Yüksek İhtisas Eğ. ve Araş. Hastanesi, İstanbul İlgili yazar e-posta/ Corresponding author e-mail: ercan 73@yahoo.com 
prevalence. For this reason, it is necessary to encourage local governments and non-governmental organizations to be more effective in the support and protection of central governments.

Keywords: Disaster Management, Natural Disasters, Social Services

\section{GİRIŞ ve KURAMSAL ÇERÇEVE}

İklim ve kuraklık gibi tabiat şartlarının veya yeryüzünün jeolojik davranışlarının bir sonucu olarak, bazen de insanların hazırladığı sebeplerin etkisiyle oluşan afetlerin; maddi ve manevi ağır sonuçları, toplumlar üzerinde çoğu zaman yıkıcı etkileri bulunmaktadır. Afetlerin neden olduğu can ve mal kayıpları telafi edilemeyecek düzeylere çıkabilmektedir (Altun, 2017).

Yaşadığımız gezegenin her yerinde mütemadiyen afet boyutlarında olaylar yaşanmakta, insanlar, çevre ve yatırımlar bu afetlerden olumsuz etkilenmektedir. 2004'de Güney Asya bölgesinde yaşanan deprem ve tsunami, 2005'de Pakistan'da yaşanan deprem, ABD'de çıkan Katrina adlı kasırga, 2009'daki Çin depremi, 2010'daki Haiti ve Şili depremleri, Pakistan'daki sel afeti ve 2012'deki Japonya depremi belli başlı olaylar şeklinde kayıtlara geçmiştir. Bazen Afrika'da olduğu gibi kuraklıklar da felaket boyutlarına yükselmektedir (Özceylan ve Coşkun, 2012).

Türkiye'nin coğrafik durumu nedeniyle afet ve felaketlerden yana sakin kalamaması bilinen bir olgudur. Her olayın sonunda fiziksel mekânlarda ve sosyal yapıda önemli değişiklikler, göçler, nüfus hareketleri ve yatırımlar gibi etkileri olmuştur. Afetlerin ülke kaynakları ve insanlar üzerinde yıkıcı ve tüketici sonuçları olduğu da bir gerçektir. Geçmiş olaylar incelendiğinde insanların doğal kaynaklı afetlere karşı direncinin oldukça düşük kaldığı ve çok yönlü etkilere maruz kaldığı görülmektedir. Doğal olayların genelinde tahmin ve hazırlık güçlüğü olduğu gibi, meydana gelişleri sırasında önlenemez ve müdahale edilemez boyutlarda yaşanması da ayrı bir zorluktur. Kaçınılmaz sonuçlar önlenemeyince, birlikte yaşamayı öğrenmek ve en az zararla kurtulmak için hazır olmak gerekmiştir. Her zaman ve her ülkede yaşanan irili ufaklı afetlere karşı, yerel imkânlar ölçüsünde hazırlık yapmak ve koruma-destek planları hazırlamak genel bir yaklaşımdır. Afetlerin neden olduğu zararlar olayın büyüklügüne ve etkilenen yerleşim birimlerinin durumuna göre değişmektedir (İbiş ve Kesgin, 2014).

Afet ve benzeri olaylardan sakınmak veya olay sırasında hizmetlerin sürekliliğini sağlamak üzere uygun düzeyde ve miktarda cihaz ve sistemlere gerek duyulmaktadır. Hayatın olağan akışı içinde zorunlu ihtiyaçlar haline gelen ulaşım, haberleşme ve enerji kaynaklarının dağıtılması gibi alt yapı tesisleri büyük bir deprem sonucu servis dışı kalabilir. Ülkemizde 1939 ve 1992 yıllarında yaşanan Erzincan depremleri, 1999 Gölcük depremi ve 2011'de yaşanan Van depreminin bu tür etkileri görülmüş ve yaşanmıştır (Özler, 2011).

Sosyal hizmetler yaklaşımı, deprem ve yangın gibi büyük felaketlerden önce hazırlanmayı, eğitim ve donatım açısından yeterli ekiplerin koordineli çalışmalarını gerektirir. Afetler yaşandıktan hemen sonra acil tıbbi yardımların verilmesiyle beraber, hemen devreye girmesi ve bu sürecin afetzedeler açısından en rahat geçmesini sağlaması gereken disiplin sosyal hizmetlerdir. Yetersiz ve yanlış verilen sosyal hizmetlerin can ve mal kaybını yükseltme etkisinde olacağı da açıtır.

\subsection{Afet ve Afet Türleri}

İnsanların hayatını ve yaşadığı çevreyi önemli ölçüde etkileyen afet olaylarının büyük bir bölümü tabiat olaylarından kaynaklanır. Geniş çaplı yıkım veya hasara yol açan olaylara afet, birden fazla afet çeşidinin bir arada meydana gelmesine de afat denir. Afetlerde geniş yerleşim bölgelerinin, 
çok sayıda insanın ve diğer canlıların zarar görmesi söz konusudur. Afet olaylarının geneli önceden bilinse de önlenemez, meydana geldiği sırada durdurulamaz.

Türkiye'de afetle mücadele ve afet yönetiminde kurumsal çözümler için teşkilatlanan Afet ve Acil Durum Yönetim Başkanlığı (AFAD) gereken hazırlık ve eğitimleri koordine etmektedir. Afet farkındalık eğitimlerini her seviyede vermek üzere ayrı bir yapılanma içine gitmiştir. Bu eğitimler sırasında afet olaylarını; her hangi bir bölgedeki toplumun hepsi veya bir kısmını etkileyen, ekonomik, sosyal ve ekolojik sonuçları oldukça ağır olan, soplumun yaşam düzeninin bozulmasına yol açan, yerel halkın baş edemediği büyük çaplı olaylar şeklinde tanımlamaktadır. Kişi ve kurumların ekonomik dengesi tamamen bozan afetlerin çıkış nedeni deprem, yangın, sel, erozyon, kuvvetli yağış ve çı̆̆ gibi doğal nedenler olabileceği gibi; fabrika yangınları, kimyasal patlamalar, maden kazaları gibi teknolojik nedenler ve savaşlarla birlikte terör olaylarının yer aldığı insani nedenler de olabilir. Afetlerin nedenleri ve oluş şekilleri yerine, etkilenen insanların sayısı ve durumu açısından değerlendirmek ve öncelikleri bu şekilde sıralamak lazımdır (Seyyar ve Yumurtacl, 2016).

Tabiat ortamında insanların kullanabildiği kaynaklar, madenler, elementler ve benzeri imkânlar olduğu gibi, gerekli tedbirler alınmadığında çok büyük hasar ve kayıplara neden olabilecek kontrol edilemez doğal olaylar da vardır. Doğal olaylardan zarar görebilme riski alınan tedbirler ışığında farklı seviyelere inebildiği gibi oldukça yükselmesi de mümkündür. Bu durumda doğal afetlere sadece doğal denilerek kenarda durmak doğru ve mantıklı olmayacaktır. Aynı şiddette meydana gelen bir depremin farklı yerleșim birimlerinde farklı hasara ve insan kayıplarına yol açması doğal olay yapısından ziyade temsil ettiği risklere karşı alınan tedbirle alakalıdır. Bazı doğal olayları tetikleyenler insanların davranışları ve doğaya etkileri olduğu için risk değerlemesinin ve alınacak önlemlerin doğru hesaplanması önemlidir. Asıl olan doğaya mümkün olduğu kadar müdahale etmemektir. Çünkü bu müdahaleler sonrasında risklerin aşırı yükselmesi kaçınılmazdır (Kırıkkaya, Oğuz Ünver, ve Çakın, 2011).

Afet hallerinde dirençlilik ise kişisel nitelikler ve çevre unsurlarıyla ilintilidir. Toplumsal, doğal ve mimari yapılar arasında kendiliğinden gelişen direnç ve beklenen kırılganlıkların oluşturduğu çok yönlü oluşum sayesinde, istenmeyen bir olay yaşandığında kendini koruyabilme ve üstesinden gelebilme gücünün seviyesi ile olayın kendisinin şiddeti seviyesi tehlike, risk ve felaket sınırlarını belirler (Cutter vd., 2008). Afet hallerinde kötü etkilerle başedebilme yetisi direnç seviyesi ve gücüyle ilgilidir. Şayet direnç gücü ve seviyesi aşllırsa afetlerden etkilenme yoğunluğu ve sürekliliği de etkinin şiddetine göre değişir. Afetlere karşı kişisel ve toplumsal düzeyde eylem ve plan birliğinin olması, teknik ve psikolojik hazırlıkların yapılması, direnç gücünü olumlu yönde etkileyen temel unsurlardır (Varol ve Buluş Kırıkkaya, 2017)

Yaşadığımız kent ve şehir alanlarının büyük bir çoğunluğu taşkın ovalarında kurulmuştur. Çünkü tarım alanlarına yakınlığı, ulaşım kolaylığı ve iklim yumuşaklığı buraları cazip kılmaktadır. Ayrıca yakında bulunan akarsulardan yaşamsal ihtiyaçlar, tarım sulaması, sanayi kullanımı ve taşımacılık gibi alanlarda fayda sağlanır. Kentsel yapıların beton ve asfalt yoğunluğu nedeniyle yağışların toprağa geçiş miktarı az ve uzaklaştırılma hızı düşük olur. Bu yüzden kuvvetli yağışlarda gerek yağmur sularının gerekse yakınlardaki akarsuların taşkın ve selleri görülmektedir. Su taşkınları ve seller hız, yoğunluk ve miktarlarına göre kentsel ve tarımsal alanlarda maddi hasarlara, altyapıların çökmesine ve bazen de can kayıplarına neden olmaktadır. Yerleşim yerlerinin büyüklügü sel ve taşkın risklerini de arttırmaktadır (Tingsanchali, 2012).

\subsection{Afetlerin Etkileri}

Doğal afetlerin fiziksel etkileri kadar siyasal etkileri ve sonuçları da gözlemlenebilir. Afet hallerinde dönüm noktaları, kritik eşikler ve tarihsel anlar şeklinde tanımlanabilecek zaman dilimleri veya hasar durum sonuçları söz konusudur. Afet etkilerinden korunmak veya hasar 
kontrolü sağlamak üzere hızlandırılmış bürokrasiye geçebilme yeteneği ile öngörülen kötü sonuçlardan korunma sağlanabilir. Küresel iletişim ve koordinasyon kalitesini yükseltmek üzere kamu dışındaki kaynaklardan profesyonel yönetim hizmetleri de sağlanabilir. Hint Okyanusu'nda meydana gelebilecek tsunamilere karşı ve Katrina Kasırgası'nda olduğu gibi afet izleme ve yapılanma hizmetlerinin özelleștirilmesi ile kaynakların verimli kullanımı ve hızlı hareket kabiliyetine erişilmektedir. Felaketler ve afetler toplum ve ülkelerin tarihinde kritik etkiler yaparak siyasal yönetimlerde değişikliklere de yol açabilmektedir. 1985'de meydana gelen Meksika Şehri ve 1972'de olan Nikaragua depremleri de bahsedilen şekilde sonuçlara yol açmış, siyasal yapıda ve politikalarda hem yerel hem de ulusal düzeyde gelişmeleri tetiklemiştir (Pelling ve Dill, 2010).

Afet olaylarının seviyelendirilmesi, neden oldukları ölümler, sakatlanmalar, yaralılar, fiziksel zarar ve ziyanlar, maddi ve manevi zararlar sayesinde yapılmaktadır. Bütün bu kayıp ve zararlar içinde en değerlisi insan hayatı olduğu için, afetlerin boyutunu neden oldukları ölümler dikkate alınarak belirlemek gibi bir yaklaşım bulunmaktadır (Erkal ve Değerliyurt, 2009).

Afet olaylarının boyutlarını etkileyen değişkenler kısaca şu şekilde sıralanabilir:

- Afetin maddi boyutları ve çevre etki gücü,

- İnsanların yaşam alanlarına olan mesafesi,

- Etkilenen insanların ekonomik seviyesi,

- Bölgedeki nüfus yoğunluğunun yükselmesi,

- Maden ve sanayi gibi riski yüksek bölgelerin yerleşim yerleri içinde kalması veya sanayi yatırımlarının riskli yerlerde toplanması,

- Doğal bitki örtülerinin ve çevre sisteminin bozulması veya çevre sistemine uyumsuz ve zararlı uygulamalar,

- Cehalet ve yetersiz kalan eğitimler,

- Afetler yaşanmadan önce insanların ve devletin hazırlık yapabilme becerisi ve bu bilincin tüm kesimler içinde yaygınlığı,

Sayılan değişkenlerin başta bulunan ikisi kelimenin tam anlamıyla doğal nedenler arasında değerlendirilebilir. Ancak diğer değişkenler tabiatla ilgili değil, insan topluluklarının yerleșim, üretim ve doğal kaynakları kullanma tarzı ile ilgilidir. Meydana gelen olayların etki büyüklügü ve yaygınlığı nedeniyle resmi kurumlar tarafından afet bölgesi ilan edilmesi beklenmeksizin müdahale edilmesi gerekebilir. Yaşanan ölümler ve yaralanmalar acil kararlar almayı ve hasarın daha fazla büyümesini önlemeye yönelik olmalıdır (Erkal ve Değerliyurt, 2009).

\subsection{Afet Yönetimi}

Afet yönetimi teknik, sosyal ve ekolojik çevre gibi sistem yönetimlerinin risk yönetimiyle harmanlandığı özel bir kavramdır. Küresel sorunlar, iletişim, ticaret ve çatışma yoğunlukları, toplumlar arası dengesizlikler, yönetim sistemlerinin farklılıkları gibi değişkenlerle etkileşim halinde çalışmak durumundadır. Bu tür yönetim sistemleri çok merkezli çalışmayı, çoklu ölçeklere sahip olmayı, tehlike ve acil durumların yapısına göre esnek mimarileri desteklemeyi gerektirir. Afet yönetimi, siyasal yönetimin içinde bulunmak ve genel yönetime uyumlu çalışmak zorundadır. Yönetim zafiyetleri ve koordinasyon sorunları ABD'de meydana gelen Katrina Kasırgasında olduğu gibi yoğun zafiyetlere ve mağduriyetlere yol açabilir (Tierney, 2012).

Devlet-sivil toplum ilişkileri, ekonomik örgütlenme ve toplumsal geçişler afet yönetişimi üzerinde etkilere sahiptir. Afet yönetimini değerlendirmek için çeşitli önlemler kullanılabilir; Bu yeni çalışma alanında, etkili yönetişime katkıda bulunan faktörler ve yönetişim yaklaşımlarının uzun vadeli sürdürülebilirliğe ne ölçüde katkıda bulunduğu gibi diğer konularda daha fazla araştırmaya ihtiyaç vardır.Afet hallerinde gereken reaksiyonu vermek üzere toplumun hazır edilebilmesi için 
afet süreçlerinin kısımlar halinde irdelenmesi lazımdır. "Afet Yönetimi” denilince, insanlardan veya doğadan kaynaklanabilecek afetlerin tahmin edilerek hazırlık yapılması ve mümkünse engellenmesine yönelik çalışmalar en başta akla gelmektedir. Afet anında insanların ve diğer kaynakların koordinasyonu, kurumlar arasında işbirliğinin sağlanması, iletişim ve haberleşmenin de dahi olduğu bir genel süreç yönetimi söz konusudur (Tuncay, 2004).

Günümüz teknolojisiyle pek çok şeyi başarabilmelerine rağmen, insanların büyük çaplı doğal olayları ve deprem ya da firtına gibi felaketleri önleme gücü yoktur. Bu tür olayların önlenmesinde veya olay anında sorunların giderilmesinde imkân dahilinde bulunan işler kısıtlıdır. Afetlerden korunmanın en iyi yolları, afetler meydana gelmeden önce tahmin ve hazırlık yapabilme yeteneğini arttırmak, bilimsel çalışma ve deneyler ışığında afetten korunma yöntemlerini ve teçhizatını geliştirmek, afetlere dayanıklı binalar ve kentler inşa etmek, afet olaylarına karşı önceden planlı süreç yönetimleri oluşturmaktadır. En başta doğal kaynaklı olanlar gelmek üzere, afetlerin detaylı şekilde incelenmesi, tanımlanması ve sistematik yönlerinin çözümlenerek mümkün olan en az zararla geçiştirilmesini sağlamak üzere yapılan işlerin tamamına "Afet Yönetimi" demek mümkündür. Afet yönetimine paralel olarak gelişen ve işletilen süreçlerden birisi de "Risk Yönetimi", yani erken algllama, ikaz ve koruma işleridir. Afetlerin etkilerini anlama, çözümleme, hasar giderme, güçlendirme vb. afetlerden sonra yapılacak işler ise "Kriz Yönetimi" başlığı altında değerlendirilir. Kısacası, afetlerin her aşamasında süreçleri yönetebilmek için afet öncelerini, afet anlarını ve afetlerden sonraki durumları birlikte değerlendirerek ilerlemek "Afet Yönetimi” süreçlerinin ortak yaklaşımı olmalıdır (Erkal ve Değerliyurt, 2009).

\subsection{Türkiye'de Afetler}

Dünya genelinde yerkabuğu hareketleri sonucu meydana gelen deprem olayları, Türkiye tarihinde de en fazla ölüm ve yaralanmalara yol açan, köklü maddi hasar ve yıkımların en büyük nedenleri olmuştur. Geçtiğimiz yüzyll içinde Türkiye'nin 120 binden fazla insanı depremlerde can vermiştir. Depremlere karşı alt yapısal ve planlama/eğitim temelli eksiklerimizin fazlalığı da ölü sayısının normalden yüksek çıkmasına neden olmuştur. Japonya gibi ülkelerle kıyaslandığında Türkiye'de deprem sonucu meydana gelen can kayıpları ve bina hasarlarının çok daha fazla olduğu görülmektedir. Eğitim eksikliği, malzeme ve bina kalitesinde yaşanan yetersizlikler ve deprem şartları dikkate alınmadan gelişen çarpık kentleşme sonucu bu vahim tablolar yaşanmıştır. Deprem riskleri harita bulgularına göre ülkemizin \%92'si deprem yaşanabilir bölgeler içinde, genel nüfus yapısının \%95'i de deprem kuşağında yer almaktadır. Son dönemlerde yaşanan en önemli depremler:

- 1992 Erzincan Depremi

- 1999 Gölcük ve Düzce Depremleri

- 2011 Van Depremi

Depremler dışında sıkça görülen olaylardan birisi de Sel Afetidir. Karadeniz kıyı kesimleri başta olmak üzere, ülkenin çeşitli yerlerinde ve kentsel alanlarda yoğun yağışlar sonucu sel afetleri de yaşanabilmektedir (Tuncay, 2004).

\section{AFETLERDE SOSYAL HIZMETLER}

Deprem gibi büyük ve afet sayılan olayların tamamı kapsam dahilinde kalan insanların hayatını her yönden etki altında bırakmaktadır. Hayatını kaybeden insanların dışında kalan kişilerin ekonomik ve sosyal yönden çöküntü yaşamaları, beden sağlığı ve psikolojik açıdan bütünlüklerinin bozulması söz konusudur. Afet öncesi var olan sorunların katlanarak karmaşıklaşması ve bireysel çabalarla giderilemeyecek duruma gelme durumu yaşanır. Temel konusu insanların sosyal ihtiyaçlarının giderilmesini organize etmek ve iyi duruma yükselmelerini 
sağlamak olan Sosyal Hizmet için afet olaylarında yer almak doğru ve gerekli bir çalışma ihtiyacıdır (Tuncay, 2004).

Meydana çıkardığı maddi ve manevi sonuçları ile derin psikolojik etkiler bırakan afetler, zaten mevcut bulunan sorunlara yenilerini de ekleyerek hayat mücadelesini daha da zorlaștırmaktadır. Afetler sonucu meydana gelen olaylar en dar kapsamıla afetzedeleri, orta alan kapsamiyla afetzedelerin aile çevresini, geniş anlamda ise bölge sakinlerini etkilediğinden, sosyal hizmet çalışmaları da bu duruma uygun yapılanma yoluna gitmektedir. Etki yelpazesinin genişliği, sosyal hizmet uzmanlarının çok boyutlu planlama ve süreç yönetimine girmelerini gerektirmektedir. Sosyal hizmet çalışmaları afetlerden önceki durumdan itibaren çalışma alanına giren hassas grupların takibini, afetler sırasında bu grupların ve afet nedeniyle takibe muhtaç duruma gelen kesimlerle birlikte değerlendirilmesini ve afet sonrasında iyileştirme çalışmalarının sürdürülmesini kapsar. Sosyal hizmetler bir yandan sahada hizmet vermeyi, diğer yandan mevcut ve gelecek şartlar için planlama çalışmalarının yapılmasını gerektiren dinamik ve çok yünlü çalışmalar ile beraber yürütülür (Seyyar ve Yumurtacı, 2016).

Psikososyal destek hizmetleri de yaşanan afetlerden sonra birey ve toplulukların normal düzene geçebilmeleri için yardımcı olan önemli sosyal hizmet alanlarından birisidir. "Psikososyal" denildiğinde karşılıklı etkileşimler içinde bulunan kişilerin ve yer aldıkları toplumsal grupların durumu düşünülmelidir. Psikososyal destek hizmetleri kişisel isteklerden bağımsız, kişiden topluma doğru ilerleyen, çalışma programına aldığı toplulukların iyiliği ve sorunlarının kaldırılması için yasal mevzuatı bilen, riskleri yaşanmadan önleyebilen ve koruyabilen yapıdadır. $\mathrm{Bu}$ yüzden geleneksel psikolojik danışmanlıktan farklı, geniş ve çok yönlü yaklaşım gerektirir (Aydın, 2012).

\subsection{Afetlerde Kamu Yönetimi ve Sosyal Hizmet}

Afetlerin yıkıcı etkileri ülkelerin kalkınmışlık seviyelerine ve afetlere maruziyet sıklıklarına göre değişkenlik göstermektedir. Az gelişmiş ülkelerde afetlerden dolayı meydana gelen can kayıpları ve maddi hasarların boyutları gelişmiş ülkelere göre çok daha yükseklerde seyretmektedir. Her afet sonucunda ülkelerin ekonomik ve sosyal gelişimine ket vurulmakta, duraklama veya çöküş yoluna meyil başlamaktadır. Afetlerin kısa dönemli yıkıcı etkilerinin yanı sıra uzun dönemli büyümeyi yavaşlatan, kaynakları tüketen bozucu etkileri de bulunmaktadır. Mesela, Nikaragua gibi az gelişmiş bir ülkeyi 1998'de vuran Mitch kasırgasının ülkedeki kalkınma potansiyelini en az 20 yıl duraklattığı hesap edilmiștir. Bu tür bir zorluğun altında kalkılabilmesi ancak kamu kaynakları ile mümkün olacaktır. Kamunun bu işlevi sağlıklı yerine getirebilmesi için çok yönlü işbirliği, plan ve program içinde çalışması icap eder. Ülkemizdeki yaşanan afetlerin her birisi acı birer tecrübe olarak kamu hafızasına da yerleşmiş ve gelecekteki afetlere karşı daha hazırlıklı olma adına kurumlar arası işbirliği ve koordinasyon yapısı gittikçe sağlamlaşan bir yapıya kavuşmuştur. 10. Kalkınma Planı içinde yer alan "Afet Yönetiminde Etkinlik Özel İhtisas Komisyonu" raporu içinde bahsedilen işbirliği ve koordinasyon vurgulanmıştır. Afetlere hazırlık ve farkındalık bilincinin yerleşmesi çok yönlü kurumsal çalışma içinde yapılabilir. Halkın her seviyede eğitilmesi, bina yapımları ve kentleşmede afetlere dayanıklı sistemlerin gözetilmesi, yerel ve merkezi yönetimin eşgüdüm sağlaması gibi rollerin tamamı için kamu gücünün organizasyon, planlama, uygulama, denetleme, yöneltme, geliştirme gibi fonksiyonlarına ihtiyaç duyulmaktadır (Leblebici, 2014).

Her ülkenin afet ve acil durum halleri için kurumsal hazırlıkları bulunur. Acil durum ve afet hallerinde altyapı sorunları dışında bu kurumlar eliyle sosyal yardımların doğrudan nakit veya ayni yardımlarla ulaşması da sağlanır. 
Amerika Birleşik Devletleri'nde Acil Durum Yönetim Ajansı (Federal Emergency Management Agency - FEMA) tarafından afet fonları yönetimi ve ödemeleri yapılır. Önemli ve acil bir durum veya felaket yaşandığında Eyalet Valilerince ABD Başkanlığından FEMA desteği ile bütçe tahsisi istenir. Başkanlık tarafından yapılan durum değerlendirmesi sonucu bu talepler yerine getirilir, bekletilir veya reddedilir. Olayın büyüklüğüne ve etki kapsamına göre eyaletin veya belli bir bölgenin Felaket Bölgesi olarak ilanına karar verildiğinde FEMA ve ilgili kuruluşların devreye girmesi sağlanır. FEMA 1979 yılında Başkan Carter tarafından çok sayıda yardım kuruluşunun birleştirilmesi ile kurulmuştur (Garrett ve Sobel, 2003).

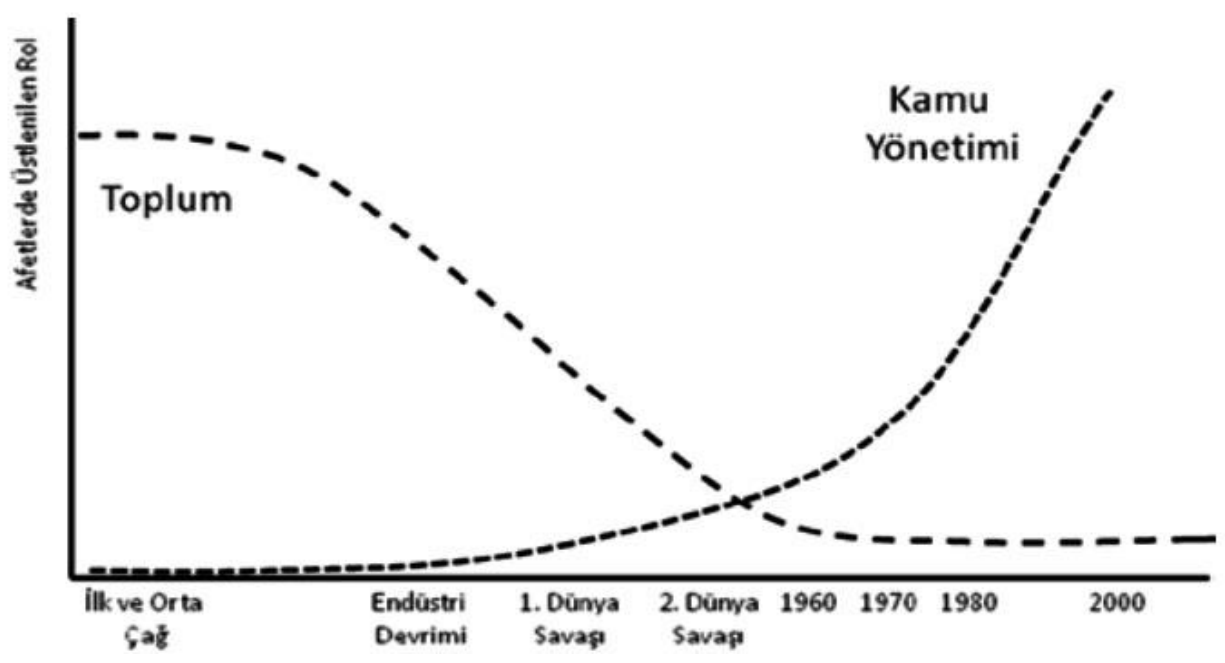

Şekil 1. Afetlerde Kamu Yönetimi ve Toplum Arasındaki Rol Dağılımının Tarihsel Süreçteki Durumu (Leblebici, 2014).

Afetlerle ilgili tüm süreçleri kapsamlı şekilde yürütme ve yönetme gücüne sadece kamu sahiptir. Etki çevresi ve maliyet boyutunun yüksekliği nedeniyle afetlere hazırlık ve mücadele için gerekli temel organizasyonu kamu gücü yapabilir. Türkiye'de afetler için münhasıran kurulan kamu kurumu "Afet ve Acil Durum Yönetimi Başkanlı̆̆ı" (AFAD) asıl hazırlık, eğitim ve organizasyonları yapan, lojistik merkezlerini ve müdahale timlerini kuran yapıdır. İlk kuruluşunda Başbakanlığa bağlı bulunuyorken, Cumhurbaşkanlığı Hükumet sisteminden sonra İç İşleri Bakanlığına bağlanmıştır. Süreç içinde doğrudan Cumhurbaşkanlığına bağlanacağına dair çalışmalar olduğu da söylenmektedir. Tüm kamu kurumlarında yer alan Sivil Savunma Uzmanları veya Sivil Savunma Amirleri eliyle, kurumların Sivil Savunma ile Afet ve Acil Durum Planları yapılmakta, personelin hizmetiçi eğitimleri sürmekte, afet olaylarına karşı kurumsal tedbirlerin alınmasına devam edilmektedir. Afet vb. olaylarda kurumların yardımlaşması için işbirliği protokolleri de kendi aralarında yapılarak planlama içinde yer verilmektedir.

\section{2. $\quad$ Afetlerde Toplumsal Sosyal Hizmet Kurumları}

Afetlerin meydana geldiği coğrafyada çevre ile birlikte o bölgede yaşayan insan toplulukları da etkilenir. Hatta o bölgede yaşamayan ama ülke veya șehir gibi yapısal ortaklıkları bulunan toplumlar ile dini ve kültürel tarihleri benzeșen diğer ülke toplumları da etkilenir. Yerel imkânların kapasitesini aşan her durum için bölge veya ülke genelinde toplumsal destek mekanizmaları devreye girer. Toplumun gösterdiği bu reaksiyona sivil toplum örgütleri öncülük ve hizmet sunumunda fiili destek sağlar. Yapılan çalışmaların başarısı ve etki gücünün isabetinde kamu ile yapılan işbirliği de oldukça önemli bir etkendir.

Ülkemizde afetlerde sosyal hizmetlerin STK düzeyinde liderliğini Kızlay yapmaktadır. 1868 yılında "Osmanlı Yaralı ve Hasta Askerlere Yardım Cemiyeti" ismiyle kurulan Kızılay, 1877 yılında 
"Osmanlı Hilali Ahmer Cemiyeti", 1923 yılında "Türkiye Hilaliahmer Cemiyeti", 1935 yılında "Türkiye Kızılay Cemiyeti" ve 1947 yılında ise "Türkiye Kızılay Derneği" adıyla tescil edilmiștir. "KIZILAY" şeklinde bilinen ismi Atatürk tarafından verilmiştir. Kuruluş amacında, nerede ve kim olursa olsun, her hangi bir ayrım yapmaksızın, yardıma muhtaç duruma düşen tüm insanların imdadına koşmak ve her yönden iyileşmelerine katkı sağlamak olan Kızılay, bu misyonuyla insanlar arasında sevgi ve dostlukla örülen dayanışma köprülerini kurmak ve geliştirmek için kendini adayan müstesna bir kurumdur (Kızlay, 2020).

Toplumu doğrudan etkileyen afet olaylarında sivil toplum kuruluşlarının da afet bölgesine gelmesi ve yardım faaliyetlerine katılması beklenen bir durumdur. Ancak afet bölgesinde yapılacak faaliyetlerin güvenlik başta olmak üzere, kurtarma ve ilk yardım gibi temel faaliyetleri bozmaması, kaynakların verimli kullanılması ve kaosun önlenmesi için koordinasyon içinde sağlanması gerekir. Güçlü bir liderlik ve organizasyon yeteneği gerektiren acil durum yönetiminde birliğin sağlanması, tek merkezden koordinasyon ile görev dağılımın yapılması önemlidir. Aksi halde çıkabilecek karmaşa içinde sağlık ve sosyal destek hizmetlerine kavuşamayan afetzedeler, kıt kaynakların çabuk tükenmesi, can ve mal güvenliğinin kaybolması gibi istenmeyen durumlar gelişebilir. Afetlerin etkilerine yönelik ihtiyaçlar giderilirken, doğru müdahaleyi sağlamak için gerekli ihtiyaçları da organizasyon ve liderlik yapısı içinde karşılamak gerekir. Öncelikleri belirlemede yapılacak hatalar can ve mal kayıplarının artmasına, afet nedeniyle hassas durumda bulunan afetzedelerin daha fazla zarar görmesine veya hizmetlere erişimlerinin gecikmesine yol açabilir (Leblebici, 2014).

\subsection{Afet Çalışanları ve Sosyal Hizmetler}

Afetler yaşandığında bölgeye gelen sosyal hizmet uzmanlarının karşılaşacakları durumlar hakkında önceden hazırlıklı ve dirençli olmaları çok önemli bir husustur. Yararlı olması gereken personelin afetlerden sonra ortaya çıkan stres ve afetzedelerden dolayı yaşadığı hassasiyet düzeyi çok yükselirse afetzedeler için fayda üretemeyeceği gibi, kendisi de afetzedeler gibi ilgi ve desteğe muhtaç duruma düşebilir. Bu yüzden sosyal hizmet uzmanlarının ve afet bölgesinde çalışan diğer personelin sahada karşısına çıkabilecek durumlar hakkında önceden eğitilerek hazırlanmaları ve psikolojik açıdan güçlendirilmeleri önemli bir husustur. Afetlere her yönüyle hazırlanmış personelin varlığı müdahale gücünün etkisini ve sahaya yansıyan faydasını arttıracaktır (Tuncay, 2004).

Afet çalışanlarının ve kurumlarının kendi aralarında da eşgüdüm ve koordinasyon sağlaması eğitim ve planlama gibi destekleme faaliyetlerinde bulunması gerekir. Bu tür ihtiyaçları gidermek üzere Türkiye çapında Afetlerde Psikososyal Hizmetler Birliği (APHB) kurulmuştur. Normal zamanlarda veya afetlerde psikososyal hizmet desteğine ihtiyacı olan birey ve topluluklara en etkili yardımı eşgüdüm sağlayarak yapabilmek ve uluslararası düzeyde örgütlenmelere katılabilmek için kurulmuş gönüllü bir yapıdır. APHB; aynı zamanda afet çalışanları arasında afet ve normal durumlar içinde karşılıklı hukuku yani hak ve sorumlulukları da belirlemeye çalışan bir örgüttür. Türkiye Kızılay Derneği, Sosyal Hizmet Uzmanları Derneği, Türkiye Psikiyatri Derneği, Türk Psikologlar Derneği, Çocuk ve Gençlik Ruh Sağlığı Derneği, Türk Psikolojik Danışma ve Rehberlik Derneği APHB üyeleridir. Protokolü 2005 yılında imzalanmış, ek protokolü de 2006 yılında imzalanarak devreye alınmıștır. Daha önce kendi halinde oluşan işbirliklerinin yerine kurumsal bir yapı altında sürekli ve sağlıklı oluşum sağlanmıştır (Yaman, 2019).

\section{SONUÇ}

Avrupa Konseyi tarafından, küresel riskleri analiz ederek anlamak ve mümkünse nedenlerine yönelik çalışmalara katkı vermek üzere INFORM örgütü kurulmuştur. Inform örgütü derlediği 
verileri analiz ederek her ülkenin afet ve risklere maruziyet açısından derecelendirmesini ve diğer ülkelere göre seviyesini çıkarır ve kamuoyuyla paylaşır. Türkiye'nin profiline bakıldığında genel INFORM riski değerlemesine göre 5 puan aldığı ve sıralamada 53. Yerde olduğu görülmektedir. Tehlike ve maruz kalma derecesinin de 7,9 gibi yüksek bir değerde ve 10. sırada bulunduğu anlaşılmaktadır. Yapılan değerlendirmelerde en yüksek afet tehlikesinin deprem olduğu ve en büyük riskin de fiziksel dayanıksızlık nedeniyle depreme bağlı yıkımlar olduğu belirtilmiștir. Türkiye'nin skorları açısından benzer ülkelere bakıldığında Senegal, Kamboçya, Meksika, Güney Afrika gibi ülkelerle birlikte listelendiği görülmektedir. Mevcut şartlarda Afetlerle başa çıkma kapasitesi eksikliğinin 3,2 gibi düşük bir değer alması ise olumlu bir durumdur (European Commission, 2020). Türkiye'nin fiziksel altyapısı ile birlikte sosyal hizmet yeteneklerini de geliştirmesi ve afetlere hazırlığını iyileştirmesi gereklidir.

Afet olaylarının farklı ve çok yönlü yapıları ile yönetimleri, etik açıdan belirsizlik ve ikilemin çok sıklıkla yaşandığı alanlardır. Yapılan çalışmalarda, afetzedeler yapılan yardımların türü, yeterliliği ve etkileri açısından afetzedeler ile yardım edenler arasında yoğun çatışma ve mutsuzlukların yaşanabildiği görülmüştür. Sosyal hizmet sunanların ve diğer acil durum destek ekiplerinin teknik teçhizat açısından ve eğitim/deneyim yeterliliklerinin beklenen seviyede olmaması afetzedelere sağlanan hizmetlerin kalite ve memnuniyet düzeylerini düşürebilir. Bazı durumlarda ise hizmet sunanlar istemelerine rağmen yasal mevzuat ve diğer kısıtlar nedeniyle gereken kalitede çalışma yapamadıklarını kendileri de ifade etmektedir (Soliman ve Rogge, 2002).

Afetlerde sosyal hizmet çalışmaları toplumun afet etkilerinden sıyrılarak normal yaşam düzenine geçebilmesi için son derece kritik öneme sahiptir. STK ve kamu gücünün sosyal hizmet alanında işbirliği yapması kapasite kullanımı ve başarılı hizmet üretiminde doğrudan etkilidir. Kamu gücüyle özellikle yüksek maliyetli ve zorlu süreçler gerektiren hizmetler verilirken, STK'ların esnek ve nokta atışlı faaliyetleri de mikro düzeyde erişim ve hizmet sunumunda öne çıkmaktadır. Sosyal hizmetlerin yapısı gereği afet öncesi durum planları ve uygulama hazırlıklarından başlayarak, afet sırasında ve afet sonrasında normal zamanlara kadar geniş bir zaman dilimini kapsamaktadır. Bu yüzden personel ve diğer kaynakların planlaması, ulaşım ve lojistik gibi temel sorunların dikkate alınarak yerel organizasyon düzeyinde yapılanması da gereklidir.

Sosyal hizmetlerin devamlılığını sağlamak üzere, toplumu bilinçlendirme ve gönüllü katılımcı eğitimlerine devam edilmelidir.

\section{KAYNAKLAR}

Altun, F. (2017). Uluslararası Kuruluşların Afetlere Yönelik Sosyal Yardım ve Sosyal Hizmet Faaliyetlerinin İncelenmesi. Journal of Social Work, 1(1), 32-54.

Aydın, D. (2012). Afet Sonrasi Psikososyal Destek Uygulamalari. İnsani ve Sosyal Araștırmalar Merkezi, 1-9.

Buluş Kırıkkaya, E., Oğuz Ünver, A., \& Çakın, O. (2011). İlköğretim Fen ve Teknoloji Programında Yer Alan Afet Eğitimi Konularına İlișkin Öğretmen Görüşleri. Necatibey Eğitim Fakültesi Elektronik Fen ve Matematik Eğitimi Dergisi, 5(1), 24-42.

Cutter, S. L., Barnes, L., Berry, M., Burton, C., Evans, E., Tate, E., \& Webb, J. (2008). A place-based model for understanding community resilience to natural disasters. Global Environmental Change, 18(4), 598-606. https://doi.org/10.1016/j.gloenvcha.2008.07.013

Erkal, T., \& Değerliyurt, M. (2009). Türkiye'de Afet Yönetimi. Doğu Coğrafya Dergisi, 14(22), 147-164. https://doi.org/10.17295/dcd.38674 
European Commission. (2020). Disaster Risk Management Knowledge Centre - INFORM. Retrieved April 20, 2020, from European Commission website: https://drmkc.jrc.ec.europa.eu/informindex/Countries/Country-Profile-Map\#

Garrett, T. A., \& Sobel, R. S. (2003). The political economy of FEMA disaster payments. Economic Inquiry, 41(3), 496-509. https://doi.org/10.1093/ei/cbg023

İbiş, E., \& Kesgin, B. (2014). Problem Analysis. Dumlupınar Üniversitesi Sosyal Bilimler Dergisi, 0(41), 225234.

Kızılay. (2020). Türkiye Kızılay Derneği. Retrieved January 3, 2020, from www.kizilay.org.tr website: https://www.kizilay.org.tr/Kurumsal/tarihcemiz

Leblebici, Ö. (2014). Afetlerde Kamu Yönetiminin Rolü ve Toplum Temelli Afet Yönetimine Doğru. Hitit Üniversitesi Sosyal Bilimler Enstitüsü Dergisi, 7(2), 457-478. https://doi.org/10.17218/husbed.95613

Özceylan, D., \& Coșkun, E. (2012). Türkiye'deki İllerin Sosyo-Ekonomik Gelișmișlik Düzeyleri Ve Afetlerden Sosyal Ve Ekonomik Zarar Görebilirlikleri Arasındaki İlişki. İstanbul Üniversitesi İşletme Fakültesi Dergisi, 41(1), 31-46.

Özler, M. (2011). Afet Olgusuna Hukuksal - Kurumsal Yaklaşım Afet ve Acil Durum Yönetimi Başkanlığı. Muğla Üniversitesi Sosyal Bilimler Enstitüsü Dergisi, 0(27), 1-14.

Pelling, M., \& Dill, K. (2010). Disaster politics: Tipping points for change in the adaptation of sociopolitical regimes. Progress in Human Geography, 34(1), 21-37. https://doi.org/10.1177/0309132509105004

Seyyar, A., \& Yumurtacı, A. (2016). Afet Odakli Acil Manevi Sosyal Hizmet Uygulamaları Bağlamında Türkiye'ye Yönelik Bir Model Önerisi. MANAS Journal of Social Studies, 5(3), 1-24.

Soliman, H. H., \& Rogge, M. E. (2002). Ethical Considerations in Disaster Services: A Social Work Perspective. Electronic Journal of Social Work, 1(1), 1537-422. Retrieved from http://www.researchgate.net/publication/255625676

Tierney, K. (2012). Disaster Governance: Social, Political, and Economic Dimensions. Annual Review of Environment and Resources, 37(1), 341-363. https://doi.org/10.1146/annurev-environ-020911-095618

Tingsanchali, T. (2012). Urban flood disaster management. Procedia Engineering, 32, $25-37$. https://doi.org/10.1016/i.proeng.2012.01.1233

Tuncay, T. (2004a). Afetlerde Sosyal Hizmet. Ankara: Hacettepe Üniversitesi Sosyal Hizmetler Yüksekokulu. Tuncay, T. (2004b). Sağlık Harcamaları. Ankara: Hacettepe Üniversitesi Sosyal Hizmetler Yüksekokulu.

Varol, N., \& Buluş Kırıkkaya, E. (2017). Afetler Karşısında Toplum Dirençliliği. Dirençlilik Dergisi, 1(1), 1-9. https://doi.org/10.32569/resilience.344784

Yaman, E. (2019). Afet ve Acil Durumlarda Aile Yılmazlığı: Literatür Taraması, Uzmanlık Tezi. Aile, Çalışma ve Sosyal Hizmetler Bakanlığl. 